\title{
Chronic musculoskeletal pain: review of mechanisms and biochemical biomarkers as assessed by the microdialysis technique
}

This article was published in the following Dove Press journal:

Journal of Pain Research

12 June 2014

Number of times this article has been viewed

\section{Björn Gerdle ${ }^{1,2}$ \\ Bijar Ghafouri ${ }^{1,3}$ \\ Malin Ernberg ${ }^{4}$ \\ Britt Larsson ${ }^{1,2}$}

'Rehabilitation Medicine, Department of Clinical and Experimental Medicine, Linköping University, Linköping, Sweden; ${ }^{2}$ Pain and Rehabilitation Centre, County Council of Östergötland, Linköping, Sweden; ${ }^{3}$ Rehabilitation Medicine, Department of Medicine and Health Sciences, Linköping University, Linköping, Sweden; ${ }^{4}$ Department of Dental Medicine, Section of Orofacial Pain and Jaw Function, Karolinska Institutet, Huddinge, Sweden
Correspondence: Björn Gerdle Rehabilitation Medicine, Department of Clinical Medicine and Experimental Sciences (IMH), Faculty of Health Sciences, Linköping University, SE 58I 85 Linköping, Sweden Tel +46763927 |9।

Email bjorn.gerdle@liu.se
Abstract: Chronic musculoskeletal pain conditions are multifaceted, and approximately 20\% of the adult population lives with severe chronic pain, with a higher prevalence in women and in lower income groups. Chronic pain is influenced by and interacts with physical, emotional, psychological, and social factors, and a biopsychosocial framework is increasingly applied in clinical practice. However, there is still a lack of assessment procedures based on the activated neurobiological pain mechanisms (ie, the biological part of the biopsychosocial model of pain), which may be a necessary step for further optimizing outcomes after treatments for patients with chronic pain. It has been suggested that chronic pain conditions are mainly driven by alterations in the central nervous system with little or no peripheral stimuli or nociception. In contrast, other authors argue that such central alterations are driven by peripheral alterations and nociceptive input. Microdialysis is an in vivo method for studying local tissue alterations and allows for sampling of substances in the interstitium of the muscle, where nociceptor free nerve endings are found close to the muscle fibers. The extracellular matrix plays a key role in physiologic functions of cells, including the primary afferent nociceptor. The present review mainly concerns the results of microdialysis studies and how they can contribute to the understanding of activated peripheral nociceptive and pain mechanisms in humans with chronic pain. The primary aim was to review molecular studies using microdialysis for the investigation of human chronic muscle pain, ie, chronic masticatory muscle pain, chronic trapezius myalgia, chronic whiplash-associated disorders, and chronic widespread pain/fibromyalgia syndrome. Several studies clearly showed elevated levels of serotonin, glutamate, lactate, and pyruvate in localized chronic myalgias and may be potential biomarkers. These results indicate that peripheral muscle alterations are parts of the activated pain mechanisms in common chronic pain conditions. Muscle alterations have been reported in fibromyalgia syndrome and chronic widespread pain, but more studies are needed before definite conclusions can be drawn. For other substances, results are inconclusive across studies and patient groups.

Keywords: algesic, biomarker, human, metabolism, nociception, pain

\section{Background \\ Living with chronic pain}

Chronic musculoskeletal pain conditions are multifaceted, and approximately $20 \%$ of the adult population lives with severe chronic pain, ${ }^{1}$ with higher prevalence in women and in lower income groups. ${ }^{2,3}$ The 12-month prevalence of neck pain in the general population and in the working population is generally between $30 \%-50 \%$ while the 12 -month prevalence of activity limiting pain is estimated to $2 \%-14 \%{ }^{4-6}$ Prevalent chronic pain conditions in the population are: neck-shoulder pain, including chronic trapezius myalgia $(10 \%-20 \%) ;^{7}$ chronic whiplash-associated disorders $(1.5 \%){ }^{8}$ and 
chronic widespread pain $(5 \%-10 \%) .{ }^{9}$ The prevalence of fibromyalgia syndrome (FMS) - a subgroup of chronic widespread pain - is $1 \%-4 \% .{ }^{10}$ Chronic masticatory muscle pain has a prevalence of approximately $10 \%$ in the population, with two-thirds being women.

Patients with these pain conditions describe widespread negative consequences: significant pain intensity; depressive symptoms; weakness; sleep-related problems; sick-leave; loss of enjoyment of life in general; and decreased emotional well-being, etc. ${ }^{11-13}$ Years lived with disability is a measure of nonfatal health outcomes from diseases and injuries. Pain conditions caused $21 \%$ of the years with disability globally. ${ }^{14}$ Low back pain was the leading single cause for years lived with disability, followed by major depressive disorder, iron deficiency anemia, and neck pain. ${ }^{14}$

\section{Biopsychosocial model of pain}

Acute and chronic pain is influenced by and interacts with physical, emotional, psychological, and social factors, and a biopsychosocial framework is increasingly applied in clinical practice. ${ }^{15-18}$ The biopsychosocial framework is seen as increasing the potential for developing better treatments and interventions. However, assessment procedures based on the activated neurobiological pain mechanisms are still lacking (ie, the bio part of the biopsychosocial model of pain); these are necessary to further optimize improvements for patients with chronic pain.

\section{Diagnoses of chronic pain conditions}

In clinical practice, physicians are obliged to classify the pain condition using the International Classification of Diseases, 10th edition (ICD-10). The diagnoses in the field of pain are vague, reflecting mainly duration and time aspects, such as chronic cervicalgia (chronic pain in the neck). Some studies have attempted to standardize criteria for diagnoses according to ICD-10. ${ }^{2}$ Several authors have called attention to the need for diagnoses based on activated pain mechanisms to improve outcomes of treatments. ${ }^{19,20}$ To address this need, the first step may be to classify nociceptive, neuropathic, psychogenic, or idiopathic pain even though distinct and validated criteria are lacking, especially for chronic pain.

Generally, chronic muscle pain diagnoses are settled by careful anamnesis and clinical examinations that reveal tender muscle at palpation, corresponding to the reported painful areas. For the diagnostics of chronic masticatory muscle pain, clinicians rely on patient reports, questionnaires, and semi-objective findings. In the Research Diagnostic Criteria for Temporomandibular Disorders, the most recent classifica- tion for chronic masticatory muscle pain, there are only two chronic masticatory muscle pain diagnoses - myalgia and myofascial pain with referral. ${ }^{21}$ The same criteria are used for both diagnoses, but myofascial pain has pain referral as an additional criteria.

The trapezius muscle is often used in morphological, electromyographical, and biochemical studies of myalgia; it is an important clinical structure and is easily accessible for invasive investigations. As trapezius myalgia is not a distinct diagnosis, according to ICD-10, researchers have used various criteria for its definition. Our group has used a standardized process to identify patients with chronic trapezius myalgia. ${ }^{22}$

The following ICD-10 diagnoses have been used to recruit patients with chronic trapezius myalgia: neck myalgia (M 79.1); cervicalgia (M 54); and cervicobrachial syndrome (M 53.1). If there are other simultaneous diagnoses, patients are excluded from the study. The potential research patients are then examined using a standardized clinical examination, using distinct inclusion and exclusion criteria to identify chronic trapezius myalgia and to exclude other conditions. ${ }^{22}$ Sometimes, chronic trapezius myalgia is part of a more extensive clinical picture, such as chronic widespread pain and/or FMS.

Chronic whiplash-associated disorders are diagnosed, based upon an anamnesis of trauma and neck pain. The severity is classified using the Quebec Criteria. ${ }^{23}$ A revised classification system for all types of neck pain conditions has been presented. ${ }^{24} \mathrm{~A}$ prominent proportion (40\%-50\%) of those with acute whiplash-associated disorders will develop a chronic pain condition. ${ }^{25,26}$

According to the American College of Rheumatology, the definition of chronic widespread pain is pain that is present in the left and right sides of the body, above and below the waist, and in the axial skeleton, all of which have lasted for at least 3 months. ${ }^{27}$ FMS is a subgroup of chronic widespread pain and, additionally, fulfils certain criteria for widespread hyperalgesia (tender point palpation). Comorbidities are common in chronic widespread pain and FMS. ${ }^{28}$

\section{Neurobiological alterations in chronic pain}

Acute pain results from a complex integrated series of events at peripheral and central levels. Acute pain mechanisms might not necessarily be valid in intermittent or chronic pain. Pace et al classified chronic pain into: 1) nociceptive/ inflammatory pain; and 2) neuropathic pain. ${ }^{29}$ There are also differences in the clinical presentation - eg, with respect 
to pulse reactions and nausea - of pain located to the skin and to muscles, as pointed out by Mense and Gerwin. ${ }^{30}$ The present review mainly discusses nociceptive/inflammatory muscle pain. Chronic pain is more complex than acute pain as extensive plastic changes of the pain transmission system can occur ${ }^{31,32}$ and by the modification of psychological and contextual factors. ${ }^{33-38}$

According to the taxonomy of the International Association for the Study of Pain, a nociceptor is defined as: "... a high-threshold sensory receptor of the peripheral somatosensory nervous system that is capable of transducing and encoding noxious stimuli." 39 Small diameter, slowly conducting afferent nerve fibers from skeletal muscle, free nerve endings of group III (A $\delta$ ), and group IV afferent (C) fibers transmit nociceptive information and have to be excited to elicit pain. ${ }^{40}$ These nociceptors are sensitive to substances released from tissues subject to various types of damages and deformations. ${ }^{41-43}$ Nociceptors respond to: single or combinations of stimuli; noxious mechanical stimuli; temperature; and chemical substances, such as $\mathrm{H}^{+}$, serotonin (5-HT), bradykinin (BKN), glutamate, substance $\mathrm{P}$ (SP), nerve growth factor (NGF), adenosine triphosphate (ATP), and potassium $\left(\mathrm{K}^{+}\right){ }^{42-44}$ In situations of trauma or inflammation, a combination of substances - the inflammatory "soup" - acts on the nociceptors. ${ }^{44}$ The nociceptor is not a static detector as plastic changes can occur, such as peripheral sensitization. ${ }^{41}$ A sensitized nociceptor has a lowered threshold for activation and can thus be activated by stimuli that are normally innocuous. ${ }^{42,43}$ According to mainly animal studies, $\mathrm{H}^{+}$, nitrogen oxide (NO), $\mathrm{K}^{+}$, ATP, NGF, tumor necrosis factor alpha (TNF- $\alpha$ ), interleukin 6 (IL-6), prostaglandin $\mathrm{E}_{2}\left(\mathrm{PGE}_{2}\right)$, and glutamate are involved in the process of peripheral sensitization. ${ }^{43-45}$ Thus, several substances appear to have both algesic and sensitization effects, eg, 5-HT, glutamate, and $\mathrm{K}^{+}$.

Studies also report that there are substances with antiinflammatory roles, eg, certain cytokines (IL-10, IL-4, IL-13, and IL-1 receptor antagonists), fatty acid metabolites (eg, prostaglandins, leukotoxins, resolvins, protectines, endocannabinoids, and N-acylethanolamines [NAEs]) and endogenous opioids. ${ }^{46-51}$ The algesic and sensitizing substances act on specific receptors of the nociceptors, eg, $\mathrm{G}$ protein-coupled receptors, receptor tyrosine kinases, and ionotropic receptors/ion channels. ${ }^{52}$ Sensitization can be accompanied by an increase in the sensitive area. ${ }^{42}$ Activation of silent nociceptors has also been reported. ${ }^{53}$ Possibly nociceptors, due to induced gene transcription and protein synthesis, can drive pain in the absence of noxious stimuli. ${ }^{41}$ In this review, we will focus on the biochemical muscle alterations associated with chronic muscle pain.

The impulses in the nociceptors are conveyed to second order neurons in the spinal medulla. ${ }^{54-56}$ At spinal level, the signal may be modulated, either amplified or attenuated, by different interneuronal pathways. If an adequate excitation of the second-order neuron occurs, the input will be transmitted to different areas of the central nervous system. Different tracts of the spinal cord have the ability to transmit nociceptive information to the central nervous system. ${ }^{54}$

Different structures in the brain - the pain matrix ${ }^{57-59}$ are dynamically involved in processing the nociception and perception of pain. ${ }^{60}$ Important areas of pain matrix appear to be anterior cingulate cortex, medial cingulate cortex, insula, prefrontal cortex, and primary and secondary somatosensory cortex (S2). In patients with chronic pain conditions, alterations in connectivity, morphological, and biochemical changes in the pain matrix have been reported. ${ }^{61-64}$ The activation of glia cells and neuroglial interactions are now also emerging as mechanisms associated with chronic pain. ${ }^{65}$

Descending supraspinal control of the spinal nociception originates from several brain regions, ${ }^{60,66}$ and this control can be altered due to behavioral, emotional, and pathological states. ${ }^{32,37,60,66-69}$ A facilitating shift of the descending system has been reported for patients with persistent pain. ${ }^{32,37,66-70}$ Alterations in the regulation and activation of inhibitory substances, eg, endorphins, gamma-aminobutyric acid, endocannabinoids, and related substances (eg, NAEs), may also contribute to disturbances in pain inhibition. Due to the above and other processes, patients with chronic pain show a clinical picture associated with signs of hyperexcitability (central sensitization) to nociception and other stimuli. One consequence of central sensitization is that the central nervous system can change pain - eg, amplification, duration, degree, and spatial extent - so that pain no longer directly reflects the peripheral noxious situation. ${ }^{71}$

Several authors have suggested that chronic pain conditions and, in particular, FMS can be driven by the above briefly described alterations in the central nervous system with little or no peripheral stimuli or nociception. ${ }^{72-74}$ Other authors have presented data indicating that central alterations are driven by peripheral alterations and nociceptive input. ${ }^{71,75-77}$

\section{Microdialysis technique}

Pain is a subjective experience and semi-objective methods like muscle palpation or assessment of pressure pain thresholds have limited sensitivity and often do not correlate 
with pain intensity. ${ }^{78}$ Microdialysis offers a potential in vivo method for studying local tissue alterations before the substances of interest are diluted and cleared by the circulatory system. The technique allows for continuous sampling of substances in the interstitium of the muscle. It has recently been pointed out that the extracellular matrix plays a key role in physiologic functions of cells, including the primary afferent nociceptor. ${ }^{79}$ The trapezius, masseter, vastus lateralis, and gastrocnemius muscles have been investigated in humans with chronic muscle pain conditions. The present review mainly concerns the results of microdialysis studies and how they can contribute to the understanding of activated peripheral nociceptive and pain mechanisms in humans with chronic pain.

The technique is performed in awake subjects and has been described in detail elsewhere. ${ }^{80-82}$ Briefly, the skin and the subcutaneous tissues above the muscle under investigation are anesthetized with a local injection (eg, $0.5 \mathrm{~mL}$ of Xylocaine $\left.^{\circledR}[20 \mathrm{mg} / \mathrm{mL}]\right)$ without adrenaline, and care is taken not to anesthetize the underlying muscle. Thereafter, a thin catheter is implanted in the muscle tissue and slowly perfused with a solution (perfusate) via an infusion pump (Figure 1). The microdialysis catheter consists of a hollow cannula to which the tip (a semi-permeable dialysis membrane) is attached.
During the perfusion molecules in the extracellular space diffuse passively across the membrane and may be collected at the outlet of the microdialysis catheter. ${ }^{82}$ This fluid, labeled the dialysate, reflects the composition of the extracellular space.

To determine the concentrations of small molecules (eg, lactate, pyruvate, glutamate, and glucose), a catheter with a $20 \mathrm{kDa}$ cut-off is suitable while a catheter with a $100 \mathrm{kDa}$ cut-off is preferred for determination of larger molecules. ${ }^{83}$ Factors that can affect the concentration (recovery) of a substance in the dialysate are: the flow rate; the diffusion rate through the tissue; the area and weight cut-off of the dialysis membrane; and the composition of the perfusate. A low flow rate results in higher relative recovery while a high flow rate results in lower relative recovery. At a very low flow (ie, $0.3 \mu \mathrm{L} / \mathrm{minute}$ ), the recovery is near $100 \%$. Detailed descriptions of relative recovery (RR) can be found elsewhere. ${ }^{81,82,84}$ Adding dextran or albumin to the perfusate can enhance RR for charged molecules, such as peptides and cytokines. Nutritive muscle blood flow can be estimated by the microdialysis ethanol technique using ${ }^{3} \mathrm{H}_{2} \mathrm{O}$ instead of ethanol. ${ }^{85,86}$ The ratio of ${ }^{3} \mathrm{H}_{2} \mathrm{O}$ in the dialysate and the perfusate (the outflow-toinflow ratio) varies inversely with the local blood flow in the tissue. ${ }^{85,86}$ The small volumes of dialysate obtained require

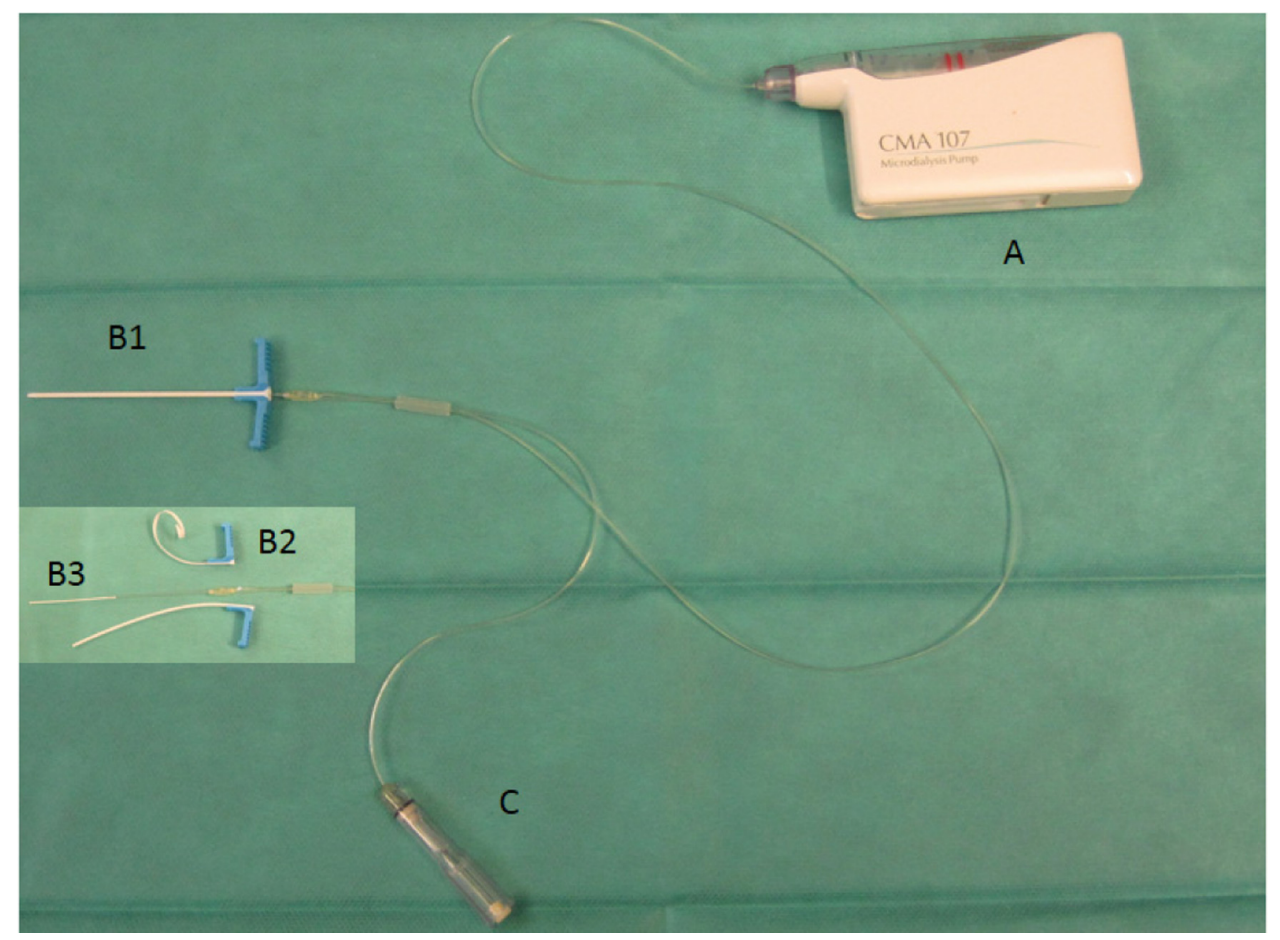

Figure I Microdialysis catheter.

Notes: Perfusate is pumped from an infusion pump (A) to the microdialysis catheter (B I), and the dialysate is collected using a microvial (C). When the catheter has been inserted into the muscle tissue, the splittable introducer (with small blue handles, B2) is removed, and the catheter (B3) is implanted into the tissue during the microdialysis experiment. The catheter (B3) consists of a hollow cannula to which the tip (a semi-permeable dialysis membrane [shown in white]) is attached. 
both analytical capacity in small volumes and a predetermination of the substances of interest.

\section{Aim}

The primary aim is to review molecular studies using microdialysis for the investigation of human chronic muscle pain, ie, chronic trapezius myalgia, chronic masticatory muscle pain, and chronic widespread pain/FMS.

\section{Methods}

\section{Criteria for inclusion and exclusion}

We have included studies that focused on chronic pain conditions affecting trapezius and masticatory muscles. To be included, the studies had to use microdialysis and had to investigate at least one patient group and one healthy control group. In the present study, we mainly have reported studies with respect to baseline differences between patient groups and control groups.

\section{Search strategy}

We have used the following search strategy in PubMed ([muscle OR pain] AND microdialysis) OR (muscle AND pain AND induced) AND (Humans[MeSH] AND (Clinical Trial[ptyp] OR meta-analysis[ptyp] OR Review[ptyp]) AND English[lang] AND adult[MeSH] AND "last 10 years"[PDat]). ${ }^{81}$ From this search, the titles and abstracts were scrutinized. If the articles were relevant and necessary, they were read for further evaluation. We also checked reference lists of these articles and included relevant articles.

\section{Results}

Table 1 lists and briefly describes some characteristics for the included studies. Different types of molecules have been investigated - algesic and inflammatory and metabolic and antinociceptive substances. From the studies in Table 1, it has been concluded that an overwhelming proportion of subjects are women. Most studies have investigated the trapezius muscle in local/regional or widespread pain conditions.

\section{Algesic and inflammatory substances Chronic masseter myalgia}

In myofascial temporomandibular disorders, significantly higher glutamate levels were found in the patient group. ${ }^{87}$

\section{Chronic trapezius myalgia}

Two out of three studies have reported increased interstitial muscle concentration of glutamate in the trapezius muscle..$^{22,88,89}$
The study that did not report any difference ${ }^{88}$ was markedly smaller than the two other studies, ${ }^{22,89}$ which may indicate a power problem.

The interstitial muscle concentration of 5-HT in the trapezius was significantly increased in all studies investigating this substance in chronic trapezius myalgia. $22,89-92$

Increased levels of BKN in myofascial pain patients with active trigger points have been reported; the levels were higher in the trapezius (with pain) than in a pain-free distant muscle. ${ }^{90,91}$ It should be noted that these studies were small. Two larger studies could not confirm their results. ${ }^{89,93}$ In the latter studies, the authors did not investigate active trigger points in the trapezius.

Interstitial levels of kallidin (KAL) have only been investigated in one study and significantly higher levels were found in chronic trapezius myalgia. ${ }^{93}$

No consistent pattern has been reported for the levels of $\mathrm{K}^{+}$in chronic trapezius myalgia. ${ }^{89,94,95}$

SP and calcitonin gene-related peptide (CGRP) concentrations were increased in active trigger points in the trapezius, and these levels were higher in the aching trapezius than in a distant pain-free muscle..$^{90,91}$

The two trapezius muscle studies investigating $\mathrm{PGE}_{2}$ found no increases, ${ }^{88,96,97}$ but one of the studies was small, ${ }^{88}$ and the other study may have had methodological problems due to the fact that the authors did not compensate for the relative recovery. ${ }^{96,97}$

Several studies of chronic trapezius myalgia have investigated cytokines, but the largest studies have not found elevated levels of cytokines. ${ }^{89,95}$ Shah et al found significant differences of cytokines for active trigger points. ${ }^{90,91}$ These authors also have compared the levels of cytokines in the myalgic trapezius (trigger points) with a muscle without pain and found higher levels in the aching muscle. These studies, however, have very small sample sizes.

\section{Chronic whiplash-associated disorders}

To our best knowledge, only one cohort of patients with chronic whiplash-associated disorders has been investigated and presented in two studies..$^{93,98}$ The 5-HT and IL-6 were significantly higher in chronic whiplash-associated disorders than in controls. ${ }^{98}$ No group differences were found in the concentrations of $\mathrm{K}^{+}$, glutamate, BKN, or KAL. ${ }^{93,98}$

\section{FMS}

FMS had increased 5-HT levels and leukotriene B4 (LTB4) levels in the masseter muscle. ${ }^{99,100}$ 
Table I Studies of chronic myalgia in humans sorted after muscle investigated

\begin{tabular}{|c|c|c|}
\hline Study & $\begin{array}{l}\text { Condition } \\
\text { Number of subjects, } \% \mathrm{~W}\end{array}$ & Substances investigated; flow rate \\
\hline \multicolumn{3}{|l|}{ Masseter } \\
\hline Ernberg et al, $1999^{99}$ & $\begin{array}{l}\text { FMS }(n=18), 100 \% \mathrm{~W} \\
\text { Localized myalgia of the temporomandibular system }(n=17), 76 \% \mathrm{~W} \\
\text { Controls }(n=10), 60 \% \mathrm{~W}\end{array}$ & 5-HT (corrected for S-5-HT); $7 \mu \mathrm{L} / \mathrm{min}$ \\
\hline $\begin{array}{l}\text { Hedenberg-Magnusson } \\
\text { et al, }\left.200\right|^{100}\end{array}$ & $\begin{array}{l}\text { FMS }(n=19), 89 \% \mathrm{~W} \\
\text { Localized myalgia of the temporomandibular system }(n=19), 74 \% \mathrm{~W} \\
\text { Controls }(n=11), 64 \% \mathrm{~W}\end{array}$ & $\mathrm{PGE}_{2}$ and $\mathrm{LTB} 4 ; 7 \mu \mathrm{L} / \mathrm{min}$ \\
\hline Castrillon et al, $2010^{87}$ & $\begin{array}{l}\text { Myofascial temporomandibular disorder pain }(n=13), 77 \% W \\
\text { Controls }(n=10), 80 \% W\end{array}$ & Glutamate; $2 \mu \mathrm{L} / \mathrm{min}$ \\
\hline \multicolumn{3}{|l|}{ Trapezius } \\
\hline Flodgren et al, $2005^{88}$ & $\begin{array}{l}\text { Chronic shoulder pain }(n=9), 100 \% \text { W } \\
\text { Controls ( } n=9), 100 \% \text { W }\end{array}$ & Glutamate and $\mathrm{PGE}_{2} ; 0.3 \mu \mathrm{L} / \mathrm{min}$ \\
\hline Flodgren et al, $2010^{96}$ & $\begin{array}{l}\text { Chronic trapezius myalgia }(n=14), 100 \% \text { W } \\
\left.\text { Controls (compared with controls }[n=20] \text { in }{ }^{97}\right), 100 \% \text { W }\end{array}$ & Lactate, pyruvate, glutamate, $\mathrm{PGE}_{2} ; 2 \mu \mathrm{L} / \mathrm{min}$ \\
\hline Rosendal et al, $2004^{22}$ & $\begin{array}{l}\text { Chronic trapezius myalgia }(n=19), 100 \% \text { W } \\
\text { Controls }(n=20), 100 \% W\end{array}$ & Lactate, pyruvate, glutamate, $5-\mathrm{HT} ; 5 \mu \mathrm{L} / \mathrm{min}$ \\
\hline Rosendal et al, $2005^{95}$ & $\begin{array}{l}\text { Chronic trapezius myalgia }(n=19), 100 \% \text { W } \\
\text { Controls }(n=20), 100 \% \text { W }\end{array}$ & $\mathrm{K}^{+}, \mathrm{LDH}, \mathrm{IL}-6$, collagen turnover; $5 \mu \mathrm{L} / \mathrm{min}$ \\
\hline Gerdle et al, $2008^{93}$ & $\begin{array}{l}\text { Chronic trapezius myalgia }(n=19), 100 \% \text { W } \\
\text { Chronic whiplash-associated disorders }(n=22), 100 \% \text { W } \\
\text { Controls }(n=20), 100 \% \text { W }\end{array}$ & $\mathrm{BKN}, \mathrm{KAL} ; 5 \mu \mathrm{L} / \mathrm{min}$ \\
\hline Gerdle et al, $2008^{98}$ & $\begin{array}{l}\text { Chronic whiplash-associated disorders }(n=22), 100 \% \text { W } \\
\text { Controls }(n=20), 100 \% \text { W }\end{array}$ & $\begin{array}{l}\text { Lactate, pyruvate, glutamate, } \mathrm{K}^{+}, 5-\mathrm{HT} \text {, IL-6; } \\
5 \mu \mathrm{L} / \mathrm{min}\end{array}$ \\
\hline Larsson et al, $2008^{89}$ & $\begin{array}{l}\text { Chronic trapezius myalgia }(n=20), 100 \% \text { W } \\
\text { Controls }(n=20), 100 \% \text { W }\end{array}$ & $\begin{array}{l}\text { Lactate, pyruvate, glutamate, 5-HT, } \mathrm{K}^{+} \text {, BKN, } \\
\text { GM-CSF, IL-I } \beta, \text { IL-6, IL-8, TNF- } \alpha \text {, IL-2, IL-4, IL-5, } \\
\text { IL-I } 0 ; 5 \mu \mathrm{L} / \mathrm{min}\end{array}$ \\
\hline Ghafouri et al, $2010^{92}$ & $\begin{array}{l}\text { Chronic trapezius myalgia, }(n=18), 100 \% \text { W } \\
\text { Controls }(n=30), 100 \% \text { W }\end{array}$ & $5-\mathrm{HT} ; 5 \mu \mathrm{L} / \mathrm{min}$ \\
\hline Ghafouri et al, 20I I 104 & $\begin{array}{l}\text { Chronic trapezius myalgia, }(n=11), 100 \% W \\
\text { Controls }(n=11), 100 \% W\end{array}$ & PEA and SEA; $5 \mu \mathrm{L} / \mathrm{min}$ \\
\hline Sjøgaard et al, $2010^{94}$ & $\begin{array}{l}\text { Chronic trapezius myalgia }(n=43), 100 \% \text { W } \\
\text { Controls }(n=19), 100 \% \text { W }\end{array}$ & Lactate, pyruvate, glucose, $\mathrm{K}^{+} ; 5 \mu \mathrm{L} / \mathrm{min}$ \\
\hline Shah et al, $2005^{91}$ & $\begin{array}{l}\text { Myofascial trapezius pain with active trigger point }(n=3) \\
\text { Controls with latent trigger point }(n=3) \\
\text { Controls without trigger point }(n=3)\end{array}$ & $\begin{array}{l}\text { BKN, CGRP, SP, IL-I } \beta \text {, TNF- } \alpha, 5-\mathrm{HT} \text {, } \\
\text { norepinephrine, } \mathrm{H}^{+} ; \text {I and } 2 \mu \mathrm{L} / \mathrm{min}\end{array}$ \\
\hline Shah et al, $2008^{90}$ & $\begin{array}{l}\text { Myofascial trapezius pain with active trigger point }(n=3) \\
\text { Controls with latent trigger point }(n=3) \\
\text { Controls without trigger point }(n=3)\end{array}$ & $\begin{array}{l}\text { BKN, CGRP, SP, IL-I } \mid \beta, \text { TNF- } \alpha \text {, IL-6, IL-8, 5-HT, } \\
\text { norepinephrine, } \mathrm{H}^{+} ; \text {I and } 2 \mu \mathrm{L} / \mathrm{min}\end{array}$ \\
\hline Gerdle et al, $2010^{102}$ & $\begin{array}{l}\text { FMS }(n=19), 100 \% \text { W } \\
\text { Controls }(n=19), 100 \% \text { W }\end{array}$ & Lactate, pyruvate, glutamate; $0.3 \mu \mathrm{L} / \mathrm{min}$ \\
\hline Gerdle et al, $2014^{103}$ & $\begin{array}{l}\text { Chronic widespread pain }(n=17), 100 \% \text { W (15 of } 17 \text { had FMS) } \\
\text { Controls }(n=24), 100 \% \text { W }\end{array}$ & $\begin{array}{l}\text { Lactate, pyruvate, glutamate, glucose, glycerol; } \\
5 \mu \mathrm{L} / \mathrm{min}\end{array}$ \\
\hline Ghafouri et al, 20I I 104 & $\begin{array}{l}\text { Chronic trapezius myalgia }(n=I I) 100 \% \text { W } \\
\text { Controls }(n=I I) 100 \% \text { W }\end{array}$ & $\mathrm{PEA}$ and SEA; $5 \mu \mathrm{L} / \mathrm{min}$ \\
\hline Ghafouri et al, $2013^{105}$ & $\begin{array}{l}\text { Chronic trapezius myalgia }(n=34) 100 \% \text { W } \\
\text { Chronic widespread pain }(n=18) 100 \% \text { W } \\
\text { Controls }(n=24) 100 \% \text { W }\end{array}$ & PEA and SEA; $5 \mu \mathrm{L} / \mathrm{min}$ \\
\hline Vastus lateralis & & \\
\hline Mclver et al, $2006^{101}$ & $\begin{array}{l}\text { FMS }(n=8), 100 \% \text { W } \\
\text { Controls }(n=8), 100 \% \text { W }\end{array}$ & Lactate; $2 \mu \mathrm{L} / \mathrm{min}$ \\
\hline
\end{tabular}

Note: *Low flow rate associated with $100 \%$ relative recovery was defined as $0.3 \mu \mathrm{L} /$ minute.

Abbreviations: W, women; FMS, fibromyalgia syndrome; 5-HT, serotonin; PGE ${ }_{2}$, prostaglandin $\mathrm{E}_{2}$; LTB4, leukotriene $\mathrm{B}_{4}$; $\mathrm{K}^{+}$, potassium; LDH, lactate dehydrogenase; BKN, bradykinin; KAL, kallidin; GM-CSF, granulocyte-macrophage colony-stimulating factor; IL-I $\beta$, interleukin I $\beta$; IL-6, interleukin 6; IL-8, interleukin 8; TNF- $\alpha$, tumor necrosis factor alpha; IL-2, interleukin 2; IL-4, interleukin 4; IL-5, interleukin 5; IL-10, interleukin I0; PEA, N-palmitoylethanolamine; SEA, N-stearoylethanolamine; CGRP, calcitonin gene-related peptide; SP, substance P; S-5-HT, Serum-5-HT. 


\section{Metabolic substances and blood flow Chronic trapezius myalgia}

Most studies concerning chronic trapezius myalgia reported increases in the interstitial concentrations of lactate. . $2,89,94,96,97^{-1}$ Methodological problems may exist in the studies conducted by Flodgren et a ${ }^{96,97}$ with respect to relative recovery as mentioned previously. ${ }^{81}$

Also, for pyruvate, a majority of chronic trapezius myalgia studies found increased interstitial concentrations of pyruvate. ${ }^{22,89,94,96,97}$ Two studies found no significant group differences for pyruvate. ${ }^{96,97}$

\section{Chronic whiplash-associated disorders}

No significant alterations were found in the interstitial concentrations of lactate and pyruvate of the trapezius muscle in patients with chronic whiplash-associated disorders. ${ }^{98}$

\section{Chronic widespread pain including FMS}

Three studies investigated chronic widespread pain/FMS patients with respect to metabolic substances. The vastus lateralis muscle - not reported if painful at rest or with altered local pain thresholds - was investigated in patients with FMS, and no differences in concentrations of lactate compared to controls were found. ${ }^{101}$ Two larger studies have investigated the trapezius muscle in chronic widespread pain/FMS. ${ }^{102,103}$ In the first study, significantly higher interstitial concentrations of lactate and pyruvate were found, ${ }^{102}$ while the other study reported significantly increased interstitial muscle concentrations of lactate in chronic widespread pain patients. ${ }^{103}$ The latter study also investigated concentrations of glucose and glycerol, but no group differences were found. Hence, the metabolic studies indicate alterations in lactate metabolism in the trapezius with chronic widespread pain/FMS.

\section{Blood flow in chronic myalgia}

Despite most chronic trapezius myalgia studies reporting significant increases in lactate, there is not a consistent picture with respect to blood flow in this pain condition or in chronic widespread pain/FMS using the microdialysis technique. $22,89,94,103$

\section{Antinociceptive substances}

Few studies have targeted muscle levels of pain-inhibitory signalling molecules. The $\mathrm{N}$-acylethanolamines (NAEs) is a family of endogenous lipid mediators that are involved in the regulation of inflammation and pain. ${ }^{49}$ The most thoroughly investigated of the NAEs is $N$-arachidonoylethanolamine (anandamide $[\mathrm{AEA}]$ ), which interacts with cannabinoid receptors and also can target transient receptor potential (vanilloid-1) receptors. Other examples of NAEs are $\mathrm{N}$-palmitoylethanolamine (PEA), $\mathrm{N}$-stearoylethanolamine (SEA), and $N$-oleoylethanolamine. Two studies have investigated the interstitial muscle levels of NAEs and reported increased levels of SEA and PEA in chronic trapezius myalgia compared to controls. ${ }^{104,105}$ The results for chronic widespread pain indicated alterations in mobilization of PEA and SEA as a consequence of exercise compared to controls. ${ }^{105}$ Hence, patients with chronic neck pain showed significantly higher levels of these substances postexercise than patients with chronic widespread pain.

\section{Omics methods for analyzing biochemical milieu of muscle interstitium}

Recently, microdialysis studies have applied omics methods to investigate the interstitium of human myalgic muscle. Both proteomic and metabolomics studies have been published indicating that these methods can be used to identify new interesting substances and processes associated with chronic myalgia. ${ }^{106,107}$ The proteomic study found that prominent proportions of the 97 identified proteins were at least two-fold higher or lower in chronic trapezius myalgia and in chronic widespread pain $(50 \%$ and $30 \%$, respectively). ${ }^{106}$ Several of the identified proteins are known to be involved in nociceptive/inflammatory processes, eg, creatine kinase, NGF, carbonic anhydrase, myoglobin, fatty acid binding protein, and actin aortic smooth muscle.

\section{Discussion}

Important conclusions based on the identified studies were:

- Several studies of local/regional muscle pain conditions indicated that 5-HT, glutamate, lactate, and pyruvate were increased in patients with chronic myalgia.

- Studies of chronic widespread pain/FMS have reported peripheral muscle alterations in 5-HT and lactate.

- Other investigated substances have only been reported in single studies or with conflicting results.

\section{5-HT}

All studies investigating 5-HT (Table 1) found significantly increased levels of this substance in the whole spectrum of severity of chronic trapezius myalgia, including chronic whiplash-associated disorders and in chronic masticatory muscle pain. The 5-HT is involved both in central and 
peripheral processes of nociception and hyperalgesia. ${ }^{108}$ Whether 5-HT has an analgesic or hyperalgesic action depends on the cell type and the type of receptor it targets. In the periphery, 5-HT is released from platelets and mast cells due to tissue damage, ${ }^{42}$ and it sensitizes afferent nerve fibers. ${ }^{108-111}$ The intramuscular administration of 5-HT into human muscle induces pain. ${ }^{12}$ There are several receptor classes and subclasses of 5-HT and especially the 5- $\mathrm{HT}_{3}$ receptor has attracted interest. But also $5-\mathrm{HT}_{1}, 5-\mathrm{HT}_{2}$, and $5-\mathrm{HT}_{7}$ have been discussed with respect to myalgia. In conclusion, the available microdialysis studies of chronic myalgia indicate that 5-HT is involved in chronic muscle pain.

\section{Glutamate}

Glutamate, a pain modulator in the human central nervous system, acts via the N-methyl-D-aspartate (NMDA), 2-amino-3-(3-hydroxy-5-methyl-isoxazol-4-yl) propanoic acid (AMPA), and kainate receptors ${ }^{113-115}$ and appears to influence peripheral pain processing. ${ }^{116-123}$ These receptors are also present on peripheral nerve terminals. Glutamate is released from peripheral afferent nerve terminals. ${ }^{124}$ Injections of glutamate increase pain intensity. ${ }^{120,125}$

Three studies of chronic myalgia reported significantly higher interstitial concentrations of glutamate,,$^{22,87,89}$ while a fourth small study found no significant group difference. ${ }^{88}$ A possible difference between subjects of these studies may contribute to the inconsistent glutamate finding. Pain history, present pain, and clinical muscular neck status of the subjects were sparsely presented in the fourth study. ${ }^{88}$ It has been suggested that the elevation of interstitial muscle glutamate alters pain sensitivity in healthy humans and is associated with pain symptoms in some chronic noninflammatory muscle pain conditions. ${ }^{126}$ The available microdialysis studies mainly support the conclusions of that review.

Interstitial concentrations of glutamate were not increased in the trapezius of chronic whiplash-associated disorders. ${ }^{98}$ Conflicting results with respect to glutamate have been reported in patients with chronic widespread pain/FMS. ${ }^{102,103}$ One difference between chronic trapezius myalgia and the two other conditions might be the more widespread hyperalgesia in chronic whiplash-associated disorders and chronic widespread pain/FMS. ${ }^{127}$

\section{Lactate and pyruvate}

The majority of studies concerning chronic trapezius myalgia have reported increases in the metabolites lactate and pyruvate. Often-suggested explanations for the higher concentration of lactate are insufficient oxygen supply and anaerobic conditions, but there is not a consistent picture with respect to blood flow in this pain condition or in chronic widespread pain/FMS using microdialysis or other techniques. ${ }^{22,89,94,103,128-130}$ Reduction in tissue oxygenation in $\mathrm{FMS}^{131}$ and in chronic trapezius myalgia ${ }^{132}$ may result in higher pyruvate and higher lactate concentrations, due to a shift toward an anaerobic state. Hence, alterations in oxygen supply cannot be excluded as a factor of importance, but other factors can also contribute, eg, decreased fitness level, increased muscle activation, and/or damaged mitochondria. Changes in the lactate-pyruvate metabolism may result in higher pyruvate levels. ${ }^{133} \mathrm{~A}$ lower fitness level is another explanation as this means more frequent reliance on anaerobic metabolism. However, it is unknown if a general deconditioning in the two pain conditions of chronic trapezius myalgia and chronic widespread pain/ FMS involves the postural trapezius. The aerobic capacity of a muscle is largely determined by the number of mitochondria and their enzymes. ${ }^{134}$ The mitochondrial density increases as a result of exercise, and an increased density results in enhanced aerobic capacity. ${ }^{135}$ Both in FMS and chronic trapezius myalgia, the trapezius muscle fibers can appear with alterations in mitochondrial content and distribution. ${ }^{131,132,136,137}$

Lactate participates in the detection of exercise stress before tissue damage occurs and can be exchanged rapidly among tissue compartments where it may be oxidized as a fuel or reconverted to form pyruvate or glucose. ${ }^{138-140}$ Lactic acid is dissociated at body $\mathrm{pH} .{ }^{141}$ Inflamed as well as ischemic tissues show lowered $\mathrm{pH} .{ }^{142,143}$ Acid-sensing ion channels (ASIC) are considered transducers for nociception and mechanosensation. ${ }^{138}$ Lactate appears to facilitate the response of acid-sensing ion channels-3 (ASIC-3) to low $\mathrm{pH} .{ }^{138}$ Lactate exposure leads to reactive oxygen species (ROS) generation and can be harmful or beneficial, depending on the level or persistence of ROS. ${ }^{144-146}$ Hence, one possibility is that the increased lactate induces, eg, ROS, which directly interacts with the nociceptive system or, in turn, activates the algesics. ${ }^{147}$ Other possible receptors for low $\mathrm{pH}$ are transient receptor potential cation channel subfamily V member 1 (TRPV1), transient receptor potential cation channel subfamily V member 4 ( TRPV4), short transient receptor potential channel 4 (TRPC4) and short transient receptor potential channel 5 (TRPC5). ${ }^{142,143,148}$

To summarize, most studies of myalgic trapezius muscles show significant increases in interstitial levels of lactate and pyruvate. 


\section{Conflicting or inconclusive results for other investigated substances $\mathrm{SP}$ and CGRP}

Two small studies of active trigger points of myofascial pain reported significant increases in SP and CGRP. ${ }^{90,91}$ Both SP and CGRP are involved as mediators of neurogenic inflammation and hyperalgesia. ${ }^{149} \mathrm{SP}$ stimulation can result in the production of inflammatory mediators and proinflammatory cytokines, ${ }^{149,150}$ which - in turn - can stimulate the production of SP. ${ }^{151}$ More studies investigating the peripheral roles of SP and CGRP in chronic myalgia are needed.

\section{$\mathrm{K}^{+}$}

When reviewing the literature, no consistent pattern of increased $\mathrm{K}^{+}$was found in patients with chronic trapezius myalgia ${ }^{89,94,95}$ or with chronic whiplash-associated disorders. Increased interstitial $\mathrm{K}^{+}$levels may be related to muscle pain. ${ }^{152}$ In acute tissue trauma, $\mathrm{K}^{+}$is a component of the "inflammatory soup" and is characterized as an algesic substance. ${ }^{153}$ The role of $\mathrm{K}^{+}$in chronic myalgia pain is unclear at the moment.

\section{$B K N$ and $K A L$}

BKN and KAL are kinins that are produced by the kallikreinmediated enzymatic cleavage of kininogen. ${ }^{43,154,155}$ The two kinins have been suggested as algesic kinins involved in muscle pain. Animal studies have shown that BKN can have both algogenic and sensitizing functions with respect to the nociceptors. ${ }^{154,156}$ Four studies investigating the interstitial concentrations of BKN and/or KAL were found.$^{89-91,93}$ The difference in results with respect to BKN among these studies could be because the alterations in BKN might be very localized, ie, in the trigger points, ${ }^{90,91}$ and not generally found in the aching trapezius muscle. ${ }^{89,93} \mathrm{KAL}$ was only investigated in one study and increased in chronic trapezius myalgia but not in the trapezius of chronic whiplash-associated disorders. ${ }^{93}$ Clearly, more pathophysiological in vivo studies are necessary to understand the roles of BKN and KAL for nociception and pain in patients with chronic muscle pain.

\section{Prostaglandins and leukotrienes}

Eicosanoids are substances produced in various cell types in response to tissue trauma by the breakdown of arachidonic acid in the cell wall, leading to the formation of prostaglandins and leukotrienes. Both these substances are suggested as potential pain mediators in chronic myalgia. $\mathrm{PGE}_{2}$ has been of particular interest for inflammatory pain and in delayed onset muscle soreness. The probable role of $\mathrm{PGE}_{2}$ is as a sensitizer of nociceptors. However, we only found two studies investigating this substance in chronic myalgia and neither found increased levels. ${ }^{96,100}$ In patients with FMS, one study reported significantly elevated levels of LTB4 in the masseter muscle. ${ }^{100}$ In conclusion, the roles of prostaglandins and leukotrienes in chronic myalgia are unclear; more studies of these substances may be needed.

\section{Cytokines}

Several direct and indirect pathways link cytokines with nociception and hyperalgesia. ${ }^{43,157,158}$ Four studies investigated cytokines in chronic trapezius myalgia, but significant differences were only found for active trigger points..$^{90,91}$ Larger studies have not found elevated levels of cytokines. ${ }^{89,95}$ The latter studies might have had technical problems due to the catheters used. On the other hand, increased IL-6 was found in the chronic whiplash-associated disorders study using the same type of custom-made catheters. ${ }^{98}$ The study by Helmy et al indicates the need to carefully review methodology aspects when determining the levels of cytokines. ${ }^{159}$

\section{NAEs}

Knowledge about peripheral antinociceptive processes in human chronic myalgia is very insufficient. Two studies, partly using the same subjects, found significant increases in two NAEs in the chronic trapezius myalgia and alterations in the mobilization of these two substances in chronic widespread pain. ${ }^{104,105}$ Larger studies also focusing on other NAEs and other myalgic muscles are necessary before any definite conclusions can be drawn with respect to chronic myalgia.

\section{Future perspectives}

Several of the microdialysis studies identified in the present review have few subjects, which entails the risk of low power and inconclusive results. Results also need to be confirmed by independent groups to be valid. Patient cohorts need to be better characterized with respect to inclusion and exclusion criteria, diagnoses and their criteria, pain severity, psychological stress, work participation, and sick leave. There is also a need to better characterize the physical fitness level of the subject and, if possible, the daily activity pattern of the investigated muscle, eg, with respect to working tasks. A global measure of the severity of the investigated pain condition can be an advantage when comparing studies.

The subjects of microdialysis studies are nearly exclusively women, which reasonably is a consequence of the higher prevalence of the most chronic myalgias in women. 
Hence, future studies ought to include men and compare mediator levels between sexes.

Another factor to consider may be diurnal variations in some biomarker levels, which should be controlled for by taking samples at the same time of the day. Tissue fluid levels of biomarkers may also be influenced by factors such as age, sex, menstrual cycle, food intake, and body mass, which must be considered in future studies.

Reasonably, a number of substances can be released and altered in the milieus of the nociceptors. Only a limited number of substances have been investigated using the microdialysis technique and are reviewed in the present review. Hence, other substances could be of importance for the genesis and maintenance of chronic muscle pain. Even though there are a few studies concerning NAEs and endocannabinoids there is a surprising gap concerning more well-known inhibitory endogenous substances such as opioids. There is also a lack of studies concerning anti-inflammatory cytokines and other fatty acid metabolites, eg, prostaglandins, leukotoxins, resolvins, and protectins. Hitherto, the limited volumes of dialysate obtained have made it impossible to analyze more than certain single biomarkers. The development of more sensitive methods that can combine analyses of several painrelated substances will probably improve knowledge about peripheral mechanisms behind chronic myalgia. Methods from the omics field using nano liquid chromatography or capillary electrophoresis in combination with mass spectrometry may be important tools to understand the complex relationship of the substances involved in chronic myalgia. Pain research will increasingly turn to this powerful technology that could hopefully provide novel and exciting insights in the field.

The development of omics methods also emphasizes the need to use multivariate data analysis. The omics methods are capable of measuring hundreds or even thousands of substances simultaneously. Traditional statistical methods assume markedly higher numbers of subjects than dependent variables, but the omics methods produce the opposite, ie, markedly more dependent and intercorrelated variables than subjects. Hence, using partial least squares regression analyses, cluster analysis, and principal component analysis may represent a complementary approach to the traditional statistical methods for a better understanding of the complex biochemical alterations that may occur in chronic musculoskeletal pain and when sensitization processes may be present in the group with myalgia but not in healthy controls. In future larger studies, it is important to investigate group differences. These studies also need to consider that when comparing a muscle with chronically sensitized nociceptors with a healthy muscle, no group differences may exist for a substance even though correlations may exist between the substance under consideration and habitual pain intensities and pain thresholds in the patient group.

\section{Conclusion}

After reviewing the literature, it can be concluded that several studies clearly show elevated levels of 5-HT, glutamate, lactate, and pyruvate in localized chronic myalgias. Several alterations in metabolites and algesics have been reported in chronic widespread pain/FMS, but more studies using different designs of the microdialysis sessions are needed before more definite conclusions can be drawn about the interstitial muscle milieu in these pain conditions. For other substances, results are inconclusive across studies and patient groups.

\section{Acknowledgments}

No financial or personal relationships have inappropriately influenced this work. This study was supported by: the Swedish Council for Working Life and Social Research (2010-0683, 2007-0760); the Swedish Research Council (2010-2893); the Swedish Rheumatism Association; the Swedish Dental Association; the Karolinska Institutet; and Linköping University. The funders had no role in the study design, data collection and analysis, decision to publish, or preparation of the manuscript.

\section{Disclosure}

The authors report no conflicts of interest in this work.

\section{References}

1. Breivik H, Collett B, Ventafridda V, Cohen R, Gallacher D. Survey of chronic pain in Europe: prevalence, impact on daily life, and treatment. Eur J Pain. 2006;10(4):287-333.

2. Larsson B, Søgaard K, Rosendal L. Work related neck-shoulder pain: a review on magnitude, risk factors, biochemical characteristics, clinical picture and preventive interventions. Best Pract Res Clin Rheumatol. 2007;21(3):447-463.

3. Gerdle B, Björk J, Henriksson C, Bengtsson A. Prevalence of current and chronic pain and their influences upon work and healthcare-seeking: a population study. J Rheumatol. 2004;31(7):1399-1406.

4. Côté P, van der Velde G, Cassidy JD, et al; Bone and Joint Decade 2000-2010 Task Force on Neck Pain and Its Associated Disorders. The burden and determinants of neck pain in workers: results of the Bone and Joint Decade 2000-2010 Task Force on Neck Pain and Its Associated Disorders. Spine (Phila Pa 1976). 2008;33(Suppl 4):S60-S74.

5. Croft PR, Lewis M, Papageorgiou AC, et al. Risk factors for neck pain: a longitudinal study in the general population. Pain. 2001;93(3): 317-325.

6. Hogg-Johnson S, van der Velde G, Carroll LJ, et al; Bone and Joint Decade 2000-2010 Task Force on Neck Pain and Its Associated Disorders. The burden and determinants of neck pain in the general population: results of the Bone and Joint Decade 2000-2010 Task Force on Neck Pain and Its Associated Disorders. Spine (Phila Pa 1976). 2008;33(Suppl 4): S39-S51. 
7. Lidgren L. Preface: neck pain and the decade of the bone and joint 2000-2010. J Manipulative Physiol Ther. 2009;32(Suppl 2):S2-S3.

8. Guez M, Hildingsson C, Nilsson M, Toolanen G, The prevalence of neck pain: a population-based study from northern Sweden. Acta Orthop Scand. 2002;73(4):455-459.

9. Gerdle B, Björk J, Cöster L, Henriksson K, Henriksson C, Bengtsson A. Prevalence of widespread pain and associations with work status: a population study. BMC Musculoskelet Disord. 2008;9:102.

10. Jesus CA, Feder D, Peres MF. The role of vitamin D in pathophysiology and treatment of fibromyalgia. Curr Pain Headache Rep. 2013;17(8):355.

11. Casarett D, Karlawish J, Sankar P, Hirschman K, Asch DA. Designing pain research from the patient's perspective: what trial end points are important to patients with chronic pain? Pain Med. 2001;2(4):309-316.

12. Robinson ME, Brown JL, George SZ, et al. Multidimensional success criteria and expectations for treatment of chronic pain: the patient perspective. Pain Med. 2005;6(5):336-345.

13. Turk DC, Dworkin RH, Revicki D, et al. Identifying important outcome domains for chronic pain clinical trials: an IMMPACT survey of people with pain. Pain. 2008;137(2):276-285.

14. Vos T, Flaxman AD, Naghavi M, et al. Years lived with disability (YLDs) for 1160 sequelae of 289 diseases and injuries 1990-2010: a systematic analysis for the Global Burden of Disease Study 2010. Lancet. 2012;380(9859):2163-2196.

15. Dworkin RH, Turk DC, Farrar JT, et al; IMMPACT. Core outcome measures for chronic pain clinical trials: IMMPACT recommendations. Pain. 2005;113(1-2):9-19.

16. World Health Organization. International Classification of Functioning, Disability and Health. Geneva: World Health Organization; 2001. Available from: http://www.disabilitaincifre.it/documenti/ICF_18.pdf. Accessed September 10, 2103.

17. Waddell G. 1987 Volvo award in clinical sciences. A new clinical model for the treatment of low-back pain. Spine (Phila Pa 1976). 1987;12(7): 632-644.

18. Pincus T, Kent P, Bronfort G, Loisel P, Pransky G, Hartvigsen J. Twenty-five years with the biopsychosocial model of low back pain-is it time to celebrate? A report from the twelfth international forum for primary care research on low back pain. Spine (Phila Pa 1976). 2013;38(24):2118-2123

19. Max MB. Towards physiologically based treatment of patients with neuropathic pain. Pain. 1990;42(2):131-137.

20. Woolf CJ, Bennett GJ, Doherty M, et al. Towards a mechanism-based classification of pain? Pain. 1998;77(3):227-229.

21. Ohrbach R, Gonzalez Y, List T, Michelotti A, Schiffman E. Diagnostic Criteria for Temporomandibular Disorders (DC/TMD). Clinical Examination Protocol. International RDC-TMD Consortium; 2013. Available from: http://www.rdc-tmdinternational.org/Portals/18/protocol_DCTMD/DC-TMD\%20Protocol\%20-\%202013_06_02.pdf. International Research Diagnostic Criteria for Temporomandibular Disorders Consortium Network; 2014. Accessed September 10, 2103.

22. Rosendal L, Larsson B, Kristiansen J, et al. Increase in muscle nociceptive substances and anaerobic metabolism in patients with trapezius myalgia: microdialysis in rest and during exercise. Pain. 2004;112(3):324-334.

23. Spitzer WO, Skovron ML, Salmi LR, et al. Scientific monograph of the Quebec Task Force on Whiplash-Associated Disorders: redefining "whiplash" and its management. Spine (Phila Pa 1976). 1995;20(Supp1 8): 1S-73S.

24. Guzman J, Hurwitz EL, Carroll LJ, et al; Bone and Joint Decade 2000-2010 Task Force on Neck Pain and Its Associated Disorders. A new conceptual model of neck pain: linking onset, course, and care: the Bone and Joint Decade 2000-2010 Task Force on Neck Pain and Its Associated Disorders. Spine (Phila Pa 1976). 2008;33(Suppl 4):S14-S23.

25. Carroll LJ, Holm LW, Hogg-Johnson S, et al; Bone and Joint Decade 2000-2010 Task Force on Neck Pain and Its Associated Disorders. Course and prognostic factors for neck pain in whiplash-associated disorders (WAD): results of the Bone and Joint Decade 2000-2010 Task Force on Neck Pain and Its Associated Disorders. Spine (Phila Pa 1976). 2008;33(Suppl 4):S83-S92.
26. Kamper SJ, Rebbeck TJ, Maher CG, McAuley JH, Sterling M. Course and prognostic factors of whiplash: a systematic review and meta-analysis. Pain. 2008;138(3):617-629.

27. Wolfe F, Smythe HA, Yunus MB, et al. The American College of Rheumatology 1990 Criteria for the Classification of Fibromyalgia. Report of the Multicenter Criteria Committee. Arthritis Rheum. 1990;33(2): $160-172$.

28. Kato K, Sullivan PF, Evengård B, Pedersen NL. Chronic widespread pain and its comorbidities: a population-based study. Arch Intern Med. 2006;166(15):1649-1654.

29. Pace MC, Mazzariello L, Passavanti MB, Sansone P, Barbarisi M, Aurilio C. Neurobiology of pain. J Cell Physiol. 2006;209(1):8-12.

30. Mense S, Gerwin RD. Muscle pain versus skin pain. In: Mense S, Gerwin R, editors. Muscle Pain: Understanding the Mechanisms. Berlin: Springer; 2010:8-12.

31. Reichling DB, Levine JD. Critical role of nociceptor plasticity in chronic pain. Trends Neurosci. 2009;32(12):611-618.

32. Kuner R. Central mechanisms of pathological pain. Nat Med. 2010;16(11):1258-1266.

33. Grachev ID, Fredrickson BE, Apkarian AV. Abnormal brain chemistry in chronic back pain: an in vivo proton magnetic resonance spectroscopy study. Pain. 2000;89(1):7-18.

34. Woolf CJ, Salter MW. Neuronal plasticity: increasing the gain in pain. Science. 2000;288(5472):1765-1769.

35. Hunt SP, Mantyh PW. Understanding the neurobiology of chronic pain: molecular and cellular biology. In: Giamberardino, MA, editor. Pain 2002 - An updated Review: Refresher Course Syllabus. Seattle: IASP Press; 2002:237-247.

36. Petersen-Felix S, Curatolo M. Neuroplasticity - an important factor in acute and chronic pain. Swiss Med Wkly. 2002;132(21-22):273-278.

37. Wilder-Smith OH, Tassonyi E, Arendt-Nielsen L. Preoperative back pain is associated with diverse manifestations of central neuroplasticity. Pain. 2002;97(3):189-194.

38. Schmidt-Wilcke T. Variations in brain volume and regional morphology associated with chronic pain. Curr Rheumatol Rep. 2008;10(6): $467-474$.

39. International Association for the Study of Pain [homepage on the Internet]. IASP Taxonomy; 1994 [updated May 22, 2012]. Available from: https://www.iasp-pain.org/Education/Content.aspx?ItemNumber=1698. Accessed September 10, 2103.

40. Mense S. The pathogenesis of muscle pain. Curr Pain Headache Rep. 2003;7(6):419-425.

41. Woolf CJ, Ma Q. Nociceptors - noxious stimulus detectors. Neuron. 2007;55(3):353-364.

42. Mense $\mathrm{S}$. Nociception from skeletal muscle in relation to clinical muscle pain. Pain. 1993;54(3):241-289.

43. Coutaux A, Adam F, Willer JC, Le Bars D. Hyperalgesia and allodynia: peripheral mechanisms. Joint Bone Spine. 2005;72(5):359-371.

44. Mense S. Algesic agents exciting muscle nociceptors. Exp Brain Res. 2009;196(1):89-100.

45. Momin A, McNaughton PA. Regulation of firing frequency in nociceptive neurons by pro-inflammatory mediators. Exp Brain Res. 2009;196(1):45-52.

46. Cunha JM, Cunha FQ, Poole S, Ferreira SH. Cytokine-mediated inflammatory hyperalgesia limited by interleukin-1 receptor antagonist. Br J Pharmacol. 2000;130(6):1418-1424.

47. Poole S, Cunha FQ, Selkirk S, Lorenzetti BB, Ferreira SH. Cytokinemediated inflammatory hyperalgesia limited by interleukin-10. $\mathrm{Br} \mathrm{J}$ Pharmacol. 1995;115(4):684-688.

48. Verri WA Jr, Cunha TM, Parada CA, Poole S, Cunha FQ, Ferreira SH. Hypernociceptive role of cytokines and chemokines: targets for analgesic drug development? Pharmacol Ther. 2006;112(1):116-138.

49. Pacher P, Bátkai S, Kunos G. The endocannabinoid system as an emerging target of pharmacotherapy. Pharmacol Rev. 2006;58(3): 389-462.

50. Piomelli D, Sasso O. Peripheral gating of pain signals by endogenous lipid mediators. Nat Neurosci. 2014;17(2):164-174. 
51. Serhan CN, Petasis NA. Resolvins and protectins in inflammation resolution. Chem Rev. 2011;111(10):5922-5943.

52. Linley JE, Rose K, Ooi L, Gamper N. Understanding inflammatory pain: ion channels contributing to acute and chronic nociception. Pflugers Arch. 2010;459(5):657-669.

53. Schaible HG, Richter F, Ebersberger A, et al. Joint pain. Exp Brain Res. 2009;196(1):153-162.

54. Almeida TF, Roizenblatt S, Tufik S. Afferent pain pathways: a neuroanatomical review. Brain Res. 2004;1000(1-2):40-56.

55. Ji RR, Kohno T, Moore KA, Woolf CJ. Central sensitization and LTP: do pain and memory share similar mechanisms? Trends Neurosci. 2003;26(12):696-705

56. Gangadharan V, Kuner R. Pain hypersensitivity mechanisms at a glance. Dis Model Mech. 2013;6(4):889-895.

57. Lee MC, Tracey I. Unravelling the mystery of pain, suffering, and relief with brain imaging. Curr Pain Headache Rep. 2010;14(2): 124-131.

58. Legrain V, Iannetti GD, Plaghki L, Mouraux A. The pain matrix reloaded: a salience detection system for the body. Prog Neurobiol. 2011;93(1):111-124.

59. Iannetti GD, Mouraux A. From the neuromatrix to the pain matrix (and back). Exp Brain Res. 2010;205(1):1-12.

60. Ossipov MH, Dussor GO, Porreca F. Central modulation of pain. J Clin Invest. 2010;120(11):3779-3787.

61. Schweinhardt $P$, Bushnell MC. Pain imaging in health and disease - how far have we come? J Clin Invest. 2010;120(11):3788-3797.

62. Apkarian AV. Pain perception in relation to emotional learning. Curr Opin Neurobiol. 2008;18(4):464-468.

63. Baliki MN, Schnitzer TJ, Bauer WR, Apkarian AV. Brain morphological signatures for chronic Pain. PLoS One. 2011;6(10):e26010.

64. Napadow V, Kim J, Clauw DJ, Harris RE. Decreased intrinsic brain connectivity is associated with reduced clinical pain in fibromyalgia. Arthritis Rheum. 2012;64(7):2398-2403.

65. Ji RR, Berta T, Nedergaard M. Glia and pain: is chronic pain a gliopathy? Pain. 2013;154 Suppl 1:S10-S28.

66. Heinricher MM, Tavares I, Leith JL, Lumb BM. Descending control of nociception: Specificity, recruitment and plasticity. Brain Res Rev. 2009;60(1):214-225.

67. Porreca F, Ossipov MH, Gebhart GF. Chronic pain and medullary descending facilitation. Trends Neurosci. 2002;25(6):319-325.

68. Ren K, Dubner R. Descending modulation in persistent pain: an update. Pain. 2002;100(1-2):1-6.

69. Robinson DA, Zhuo M. Genetic analysis of pain mechanisms. Crit Rev Eukaryot Gene Expr. 2002;12(4):275-295.

70. Julien N, Goffaux P, Arsenault P, Marchand S. Widespread pain in fibromyalgia is related to a deficit of endogenous pain inhibition. Pain. 2005;114(1-2):295-302.

71. Woolf CJ. Central sensitization: implications for the diagnosis and treatment of pain. Pain. 2011;152(Suppl 3):S2-S15.

72. Bradley LA. Pathophysiology of fibromyalgia. Am J Med. 2009; 122(Suppl 12):S22-S30.

73. Petersel DL, Dror V, Cheung R. Central amplification and fibromyalgia: disorder of pain processing. J Neurosci Res. 2011;89(1):29-34.

74. Smith HS, Harris R, Clauw D. Fibromyalgia: an afferent processing disorder leading to a complex pain generalized syndrome. Pain Physician. 2011;14(2):E217-E245.

75. Schneider GM, Smith AD, Hooper A, et al. Minimizing the source of nociception and its concurrent effect on sensory hypersensitivity: an exploratory study in chronic whiplash patients. BMC Musculoskelet Disord. 2010;11:29.

76. Staud R, Nagel S, Robinson ME, Price DD. Enhanced central pain processing of fibromyalgia patients is maintained by muscle afferent input: a randomized, double-blind, placebo-controlled study. Pain. 2009;145(1-2):96-104.

77. Staud R. Is it all central sensitization? Role of peripheral tissue nociception in chronic musculoskeletal pain. Curr Rheumatol Rep. 2010;12(6): $448-454$.
78. Wallin M, Liedberg G, Börsbo B, Gerdle B. Thermal detection and pain thresholds but not pressure pain thresholds are correlated with psychological factors in women with chronic whiplash-associated pain. Clin J Pain. 2012;28(3):211-221.

79. Reichling DB, Green PG, Levine JD. The fundamental unit of pain is the cell. Pain. 2013;154 Suppl 1.

80. Ungerstedt U. Microdialysis - principles and applications for studies in animals and man. J Intern Med. 1991;230(4):365-373.

81. Gerdle B, Larsson B. Potential muscle biomarkers of chronic myalgia in humans - a systematic review of microdialysis studies. In: Khan TK, editor. Biomarker. Open access: InTech; 2012:103-132.

82. Ernberg M, Gerdle B. Peripheral Algesic Substances in Musculoskeletal Pain Assessed by Microdialysis. In: Graven-Nielsen T, Arendt-Nielsen L, editors. Musculoskeletal Pain - Basic Mechanisms and Implications. IASP Press; 2014. In press.

83. Waelgaard L, Pharo A, Tønnessen TI, Mollnes TE. Microdialysis for monitoring inflammation: efficient recovery of cytokines and anaphylotoxins provided optimal catheter pore size and fluid velocity conditions. Scand J Immunol. 2006;64(3):345-352.

84. Olausson P, Gerdle B, Ghafouri N, Karlsson L, Larsson B, Ghafouri B. Relative recovery over time - an in vivo microdialysis study of human skeletal muscle. Scand J Clin Lab Invest. 2013;73(1):10-16.

85. Hickner RC, Bone D, Ungerstedt U, Jorfeldt L, Henriksson J. Muscle blood flow during intermittent exercise: comparison of the microdialysis ethanol technique and $133 \mathrm{Xe}$ clearance. Clin Sci (Lond). 1994;86(1):15-25.

86. Stallknecht B, Donsmark M, Enevoldsen LH, Fluckey JD, Galbo H. Estimation of rat muscle blood flow by microdialysis probes perfused with ethanol, [14C]ethanol, and 3H2O. J Appl Physiol. 1999;86(3):1054-1061.

87. Castrillon EE, Ernberg M, Cairns BE, et al. Interstitial glutamate concentration is elevated in the masseter muscle of myofascial temporomandibular disorder patients. J Orofac Pain. 2010;24(4):350-360.

88. Flodgren GM, Crenshaw AG, Alfredson H, et al. Glutamate and prostaglandin $\mathrm{E} 2$ in the trapezius muscle of female subjects with chronic muscle pain and controls determined by microdialysis. Eur J Pain. 2005;9(5):511-515.

89. Larsson B, Rosendal L, Kristiansen J, et al. Responses of algesic and metabolic substances to $8 \mathrm{~h}$ of repetitive manual work in myalgic human trapezius muscle. Pain. 2008;140(3):479-490.

90. Shah JP, Danoff JV, Desai MJ, et al. Biochemicals associated with pain and inflammation are elevated in sites near to and remote from active myofascial trigger points. Arch Phys Med Rehabil. 2008;89(1): $16-23$.

91. Shah JP, Phillips TM, Danoff JV, Gerber LH. An in vivo microanalytical technique for measuring the local biochemical milieu of human skeletal muscle. J Appl Physiol (1985). 2005;99(5):1977-1984.

92. Ghafouri B, Larsson BK, Sjörs A, Leandersson P, Gerdle BU. Interstitial concentration of serotonin is increased in myalgic human trapezius muscle during rest, repetitive work and mental stress - an in vivo microdialysis study. Scand J Clin Lab Invest. 2010;70(7):478-486.

93. Gerdle B, Hilgenfeldt U, Larsson B, Kristiansen J, Søgaard K, Rosendal L. Bradykinin and kallidin levels in the trapezius muscle in patients with work-related trapezius myalgia, in patients with whiplash associated pain, and in healthy controls - A microdialysis study of women. Pain. 2008;139(3):578-587.

94. Sjøgaard G, Rosendal L, Kristiansen J, et al. Muscle oxygenation and glycolysis in females with trapezius myalgia during stress and repetitive work using microdialysis and NIRS. Eur J Appl Physiol. 2010;108(4):657-669.

95. Rosendal L, Kristiansen J, Gerdle B, et al. Increased levels of interstitial potassium but normal levels of muscle IL-6 and LDH in patients with trapezius myalgia. Pain. 2005;119(1-3):201-209.

96. Flodgren GM, Crenshaw AG, Hellström F, Fahlström M. Combining microdialysis and near-infrared spectroscopy for studying effects of low-load repetitive work on the intramuscular chemistry in trapezius myalgia. J Biomed Biotechnol. 2010;2010:513803. 
97. Flodgren GM, Hellström FB, Fahlström M, Crenshaw AG. Effects of 30 versus 60 min of low-load work on intramuscular lactate, pyruvate, glutamate, prostaglandin $\mathrm{E}(2)$ and oxygenation in the trapezius muscle of healthy females. Eur J Appl Physiol. 2006;97(5):557-565.

98. Gerdle B, Lemming D, Kristiansen J, Larsson B, Peolsson M, Rosendal L. Biochemical alterations in the trapezius muscle of patients with chronic whiplash associated disorders (WAD) - a microdialysis study. Eur $J$ Pain. 2008;12(1):82-93.

99. Ernberg M, Hedenberg-Magnusson B, Alstergren P, Kopp S. The level of serotonin in the superficial masseter muscle in relation to local pain and allodynia. Life Sci. 1999;65(3):313-325.

100. Hedenberg-Magnusson B, Ernberg M, Alstergren P, Kopp S. Pain mediation by prostaglandin E2 and leukotriene B4 in the human masseter muscle. Acta Odontol Scand. 2001;59(6):348-355.

101. McIver KL, Evans C, Kraus RM, Ispas L, Sciotti VM, Hickner RC. NO-mediated alterations in skeletal muscle nutritive blood flow and lactate metabolism in fibromyalgia. Pain. 2006;120(1-2):161-169.

102. Gerdle B, Soderberg K, Salvador Puigvert L, Rosendal L, Larsson B. Increased interstitial concentrations of pyruvate and lactate in the trapezius muscle of patients with fibromyalgia: a microdialysis study. J Rehabil Med. 2010;42(7):679-687.

103. Gerdle B, Larsson B, Forsberg F, et al. Chronic widespread pain: increased glutamate and lactate concentrations in the trapezius muscle and plasma. Clin J Pain. 2014;30(5):409-420.

104. Ghafouri N, Ghafouri B, Larsson B, et al. High levels of $\mathrm{N}$-palmitoylethanolamide and $\mathrm{N}$-stearoylethanolamide in microdialysate samples from myalgic trapezius muscle in women. PLOS One. 2011;6(11):e27257.

105. Ghafouri N, Ghafouri B, Larsson B, Stensson N, Fowler CJ, Gerdle B. Palmitoylethanolamide and stearoylethanolamide levels in the interstitium of the trapezius muscle of women with chronic widespread pain and chronic neck-shoulder pain correlate with pain intensity and sensitivity. Pain. 2013;154(9):1649-1658.

106. Olausson P, Gerdle B, Ghafouri N, Larsson B, Ghafouri B. Identification of proteins from interstitium of trapezius muscle in women with chronic myalgia using microdialysis in combination with proteomics. PLoS One. 2012;7(12):e52560.

107. Hadrévi J, Ghafouri B, Sjörs A, et al. Comparative metabolomics of muscle interstitium fluid in human trapezius myalgia: an in vivo microdialysis study. Eur J Appl Physiol. 2013;113(12):2977-2989.

108. Sommer C. Serotonin in pain and analgesia: actions in the periphery. Mol Neurobiol. 2004;30(2):117-125.

109. Ernberg M. Serotonergic Receptor involvement in Muscle Pain and Hyperalgesia. In: Graven-Nielsen T, Arendt-Nielsen L, Mense S, editors. Fundamentals of Musculoskeltal Pain. 1st ed. Seattle: IASP Press; 2008:139-153.

110. Giordano J, Rogers LV. Peripherally administered serotonin 5-HT3 receptor antagonists reduce inflammatory pain in rats. Eur $J$ Pharmacol. 1989;170(1-2):83-86.

111. Taiwo YO, Levine JD. Serotonin is a directly-acting hyperalgesic agent in the rat. Neuroscience. 1992;48(2):485-490.

112. Ernberg M, Hedenberg-Magnusson B, Kurita H, Kopp S. Effects of local serotonin administration on pain and microcirculation in the human masseter muscle. J Orofac Pain. 2006;20(3):241-248.

113. Coggeshall RE, Carlton SM. Receptor localization in the mammalian dorsal horn and primary afferent neurons. Brain Res Brain Res Rev. 1997;24(1):28-66.

114. Hudspith MJ. Glutamate: a role in normal brain function, anaesthesia, analgesia and CNS injury. Br J Anaesth. 1997;78(6):731-747.

115. Quintero GC. Advances in cortical modulation of pain. $J$ Pain Res. 2013;6:713-725

116. Carlton SM. Peripheral excitatory amino acids. Curr Opin Pharmacol. 2001;1(1):52-56.

117. Varney MA, Gereau RW 4th. Metabotropic glutamate receptor involvement in models of acute and persistent pain: prospects for the development of novel analgesics. Curr Drug Targets CNS Neurol Disord. 2002;1(3):283-296.
118. Cairns BE, Sessle BJ, Hu JW. Characteristics of glutamate-evoked temporomandibular joint afferent activity in the rat. J Neurophysiol. 2001;85(6):2446-2454.

119. Cairns BE, Hu JW, Arendt-Nielsen L, Sessle BJ, Svensson P. Sex-related differences in human pain and rat afferent discharge evoked by injection of glutamate into the masseter muscle. J Neurophysiol. 2001;86(2):782-789.

120. Cairns BE, Wang K, Hu JW, Sessle BJ, Arendt-Nielsen L, Svensson P. The effect of glutamate-evoked masseter muscle pain on the human jaw-stretch reflex differs in men and women. $J$ Orofac Pain. 2003;17(4):317-325.

121. Svensson P, Cairns BE, Wang K, et al. Glutamate-evoked pain and mechanical allodynia in the human masseter muscle. Pain. 2003;101(3):221-227.

122. Svensson P, Wang K, Arendt-Nielsen L, Cairns BE, Sessle BJ. Pain effects of glutamate injections into human jaw or neck muscles. J Orofac Pain. 2005;19(2):109-118.

123. Tegeder L, Zimmermann J, Meller S, Geisslinger G. Release of algesic substances in human experimental muscle pain. Inflamm Res. 2002;51(8):393-402.

124. Miller KE, Hoffman EM, Sutharshan M, Schechter R. Glutamate pharmacology and metabolism in peripheral primary afferents: physiological and pathophysiological mechanisms. Pharmacol Ther. 2011;130(3):283-309.

125. Gazerani P, Wang K, Cairns BE, Svensson P, Arendt-Nielsen L. Effects of subcutaneous administration of glutamate on pain, sensitization and vasomotor responses in healthy men and women. Pain. 2006;124(3):338-348.

126. Cairns BE, Dong X. The role of peripheral glutamate and glutamate receptors in muscle pain. J Musculoskelet Pain. 2008;16(1-2): $85-91$.

127. Arendt-Nielsen L, Graven-Nielsen T. Central sensitization in fibromyalgia and other musculoskeletal disorders. Curr Pain Headache Rep. 2003;7(5):355-361.

128. Elvin A, Siösteen AK, Nilsson A, Kosek E. Decreased muscle blood flow in fibromyalgia patients during standardised muscle exercise: a contrast media enhanced colour Doppler study. Eur J Pain. 2006;10(2):137-144

129. Lund N, Bengtsson A, Thorborg P. Muscle tissue oxygen pressure in primary fibromyalgia. Scand J Rheumatol. 1986;15(2):165-173.

130. Sandberg M, Lindberg LG, Gerdle B. Peripheral effects of needle stimulation (acupuncture) on skin and muscle blood flow in fibromyalgia. Eur J Pain. 2004;8(2):163-171.

131. Bengtsson A. The muscle in fibromyalgia. Rheumatology (Oxford). 2002;41(7):721-724.

132. Larsson B, Björk J, Kadi F, Lindman R, Gerdle B. Blood supply and oxidative metabolism in muscle biopsies of female cleaners with and without myalgia. Clin J Pain. 2004;20(6):440-446.

133. Philip A, Macdonald AL, Watt PW. Lactate - a signal coordinating cell and systemic function. $J$ Exp Biol. 2005;208(Pt 24):4561-4575.

134. Weibel ER, Hoppeler H. Exercise-induced maximal metabolic rate scales with muscle aerobic capacity. J Exp Biol. 2005;208(Pt 9): 1635-1644.

135. Norrbom J. Exercise and Regulation of Mithochondrial Biogenesis Factors in Human Skeletal Muscle [doctoral thesis]. Stockholm, Karolinska Institute; 2008.

136. Bengtsson A, Henriksson KG, Larsson J. Muscle biopsy in primary fibromyalgia. Light-microscopical and histochemical findings. Scand J Rheumatol. 1986;15(1):1-6.

137. Larsson B, Björk J, Henriksson KG, Gerdle B, Lindman R. The prevalences of cytochrome $\mathrm{c}$ oxidase negative and superpositive fibres and ragged-red fibres in the trapezius muscle of female cleaners with and without myalgia and of female healthy controls. Pain. 2000;84(2-3):379-387.

138. Kim TJ, Freml L, Park SS, Brennan TJ. Lactate concentrations in incisions indicate ischemic-like conditions may contribute to postoperative pain. J Pain. 2007;8(1):59-66. 
139. Gladden LB. Lactate metabolism: a new paradigm for the third millennium. J Physiol. 2004;558(Pt 1):5-30.

140. Robergs RA, Ghiasvand F, Parker D. Biochemistry of exerciseinduced metabolic acidosis. Am J Physiol Regul Integr Comp Physiol. 2004;287(3):R502-R516.

141. Cairns SP. Lactic acid and exercise performance: culprit or friend? Sports Med. 2006;36(4):279-291.

142. Eisenhut M, Wallace H. Ion channels in inflammation. Pflugers Arch. 2011;461(4):401-421.

143. Lee Y, Lee CH, Oh U. Painful channels in sensory neurons. Mol Cells. 2005;20(3):315-324.

144. Barbieri E, Sestili P. Reactive oxygen species in skeletal muscle signaling. J Signal Transduct. 2012;2012:982794.

145. Cruz RS, de Aguiar RA, Turnes T, Penteado Dos Santos R, de Oliveira MF, Caputo F. Intracellular shuttle: the lactate aerobic metabolism. ScientificWorldJournal. 2012;2012:420984.

146. Lanza IR, Nair KS. Mitochondrial function as a determinant of life span. Pflugers Arch. 2010;459(2):277-289.

147. Kallenborn-Gerhardt W, Schröder K, Geisslinger G, Schmidtko A. NOXious signaling in pain processing. Pharmacol Ther. 2013;137(3): 309-317.

148. Schaible HG, Ebersberger A, Natura G. Update on peripheral mechanisms of pain: beyond prostaglandins and cytokines. Arthritis Res Ther. 2011;13(2):210.

149. Sacerdote P, Levrini L. Peripheral mechanisms of dental pain: the role of substance P. Mediators Inflamm. 2012;2012:951920.
150. Harrison S, Geppetti P. Substance p. Int J Biochem Cell Biol. 2001; 33(6):555-576.

151. Iannone F, Lapadula G. Obesity and inflammation - targets for OA therapy. Curr Drug Targets. 2010;11(5):586-598.

152. Graven-Nielsen T, McArdle A, Phoenix J, et al. In vivo model of muscle pain: quantification of intramuscular chemical, electrical, and pressure changes associated with saline-induced muscle pain in humans. Pain. 1997;69(1-2):137-143.

153. Marchand S. The Phenomenon of Pain. 1st edition. Seattle: IASP Press; 2012.

154. Wang H, Ehnert C, Brenner GJ, Woolf CJ. Bradykinin and peripheral sensitization. Biol Chem. 2006;387(1):11-14.

155. Riedel W, Neeck G. Nociception, pain, and antinociception: current concepts. Z Rheumatol. 2001;60(6):404-415.

156. Levine JD, Reichling DB. Peripheral mechanisms of inflammatory pain. In: Wall PD, Melzack R, editors. Textbook of Pain. 4th ed. Edinburgh: Churchill Livingstone; 1999:59-84.

157. Sommer C, Kress M. Recent findings on how proinflammatory cytokines cause pain: peripheral mechanisms in inflammatory and neuropathic hyperalgesia. Neurosci Lett. 2004;361(1-3):184-187.

158. Uçeyler N, Schäfers M, Sommer C. Mode of action of cytokines on nociceptive neurons. Exp Brain Res. 2009;196(1):67-78.

159. Helmy A, Carpenter KL, Skepper JN, Kirkpatrick PJ, Pickard JD, Hutchinson PJ. Microdialysis of cytokines: methodological considerations, scanning electron microscopy, and determination of relative recovery. J Neurotrauma. 2009;26(4):549-561.
Journal of Pain Research

\section{Publish your work in this journal}

The Journal of Pain Research is an international, peer-reviewed, open access, online journal that welcomes laboratory and clinical findings in the fields of pain research and the prevention and management of pain. Original research, reviews, symposium reports, hypothesis formation and commentaries are all considered for publication.

\section{Dovepress}

The manuscript management system is completely online and includes a very quick and fair peer-review system, which is all easy to use. Visit http://www.dovepress.com/testimonials.php to read real quotes from published authors. 